\title{
Impacts of Infectious Disease Outbreaks on Firm Performance and Risk: The Forest Industries during the COVID-19 Pandemic
}

\author{
Ståle Størdal ${ }^{1, * \mathbb{D}}$, Gudbrand Lien ${ }^{1}\left(\mathbb{D}\right.$ and Erik Trømborg ${ }^{2}(\mathbb{D}$ \\ 1 Inland School of Business and Social Sciences, Inland Norway University of Applied Sciences, P.O. Box 400, \\ Elverum, NO-2418 Lillehammer, Norway; gudbrand.lien@inn.no \\ 2 Faculty of Environmental Sciences and Natural Resource Management, Norwegian University of Life \\ Sciences, P.O. Box 5003, NO-1432 Ås, Norway; erik.tromborg@nmbu.no \\ * Correspondence: stale.stordal@inn.no
}

Citation: Størdal, Ståle, Gudbrand Lien, and Erik Trømborg. 2021.

Impacts of Infectious Disease

Outbreaks on Firm Performance and Risk: The Forest Industries during the COVID-19 Pandemic. Journal of Risk and Financial Management 14: 318. https://doi.org/10.3390/jrfm14070318

Academic Editors: Cuong Nguyen

Received: 28 June 2021

Accepted: 7 July 2021

Published: 12 July 2021

Publisher's Note: MDPI stays neutra with regard to jurisdictional claims in published maps and institutional affiliations.

Copyright: (c) 2021 by the authors. Licensee MDPI, Basel, Switzerland. This article is an open access article distributed under the terms and conditions of the Creative Commons Attribution (CC BY) license (https:// creativecommons.org/licenses/by/ $4.0 /)$

\begin{abstract}
We examine the financial performance of the forest products industry in the initial phase of the COVID-19 pandemic, employing data for publicly trading companies in the industry globally. We first examine the market investor reaction to the declaration of a pandemic by the World Health Organization (WHO) in March 2020 by conducting an event-study analysis. Then, we analyze medium-term changes in stock returns and their systematic risk by an econometric estimation of the capital asset pricing model. Our event-study analysis of the forest products industry shows that the forestry subsector was impacted more than the paper subsector when the WHO declared the pandemic. The effect was most prominent in North America. We find that the systematic risk for the forestry subsector tended to increase during 2020, until October. Again, this effect was most clear in North America. Conversely, the impact on the paper subsector was more stable.
\end{abstract}

Keywords: capital asset pricing model; COVID-19; event study; forest products industry

\section{Introduction}

On 11 March 2020, the World Health Organization (WHO) declared the COVID-19 outbreak a worldwide pandemic (World Health Organization 2021). The global stock markets had begun to experience serious setbacks weeks ahead of this announcement, plummeting in response to the initial panic caused by the spread of COVID-19.

The forest industries were one of many industries affected by the COVID-19 pandemic. A recent survey by the Food and Agriculture Organization (FAO 2020) indicates that the wood value chains were hit hard by the pandemic. However, the intensity across sectors was not homogeneous, and, in fact, the pulp and paper business reported a positive impact.

This varied response is credible given that the forest products industry sector itself is diverse and connected to different markets and value chains on the demand and supply sides. Moreover, since 2000, the forest industries have faced a period of transition, and the economic development of the global forest sector appears more uncertain and the drivers more diverse than before. As noted by Jonsson (2011), changes in forest sectors are caused by several internal and external factors, with primary drivers including globalization, global climate change, policies, regulations, and customer preferences linked to climate change, environmental policies, and regulations other than those linked to climate change. Digitalization of media has led to the stagnation and even decline of demand for printing paper, causing a substantial restructuring of the global paper industries (Hurmekoski and Hetemäki 2013).

Forestry-related assets are shown to be weakly correlated with the financial markets and to have low systematic risk (Sun and Zhang 2001). However, there are many reasons to believe that the different value chains are impacted differently by events such as financial crises and the pandemic. For example, the market for sawn wood is more cyclical than the paper market and it was impacted harder by the global financial crisis, although it 
has subsequently recovered. Ince and Nepal (2012) found that housing construction fell by close to $80 \%$ in the US between 2006 and 2009 due to the global financial crisis. The global production of wood-based panels fell by $15.6 \%$ between 2007 and 2009. However, the global production of paper and board declined by only $5.4 \%$ during this period. In addition, there are regional differences within the industry. For instance, production of wood-based panels in Asia experienced no contraction from 2007 to 2008, with production actually increasing from 2008 to 2009. Moreover, Asia maintained a steady increase in the production of paper and board throughout the financial crisis. Data for the period following the financial crisis, from 2009 to 2019, show that the global growth in production has been $9 \%$ for paper and paperboard, compared with $36 \%$ for wood-based panels (FAO 2021). The forest products industry is capital-intensive and produces fairly homogeneous products. The best performing companies, in terms of returns on investment and stock price appreciation, are generally those with the lowest cost production, which are able to manage their resource base in the most efficient and sustainable manner possible. Vertical integration and diversification influence risks and returns. Using stock market data for the forest products industry in North America from 1968 to 1986, Booth and Vertinsky (1991) found that unrelated-product and geographical diversification reduced risk, but at a significant cost in terms of the rate of return. Thomson (1991) analyzed different portfolios constructed from different sawtimber and financial market investment and found that that risk-tolerant investors may choose only timber investments, whereas more risk-averse investors will hold both timber and financial market investments. Sadorsky and Henriques (2001) found that the forest products industry is riskier than the market and its moves are procyclical. Li and Zhang (2014) analyzed the relationship between industrial timberland ownership and the financial performance of forest products companies in the US. Their results showed that holding timberland improves the profitability of a forest products company and lowers its systematic risk.

The main objective of this study is to investigate the financial performance of the forest products industry in the initial phase of the COVID-19 pandemic. To the best of our knowledge this is the first study of how the COVID-19 pandemic has affected the global forest products industry. Employing data for publicly traded companies in the industry globally, we address the following research questions.

i. What were the initial effects of the pandemic and lockdowns on the stock market returns of the forest products industries?

ii. Did these effects vary in magnitude across subsectors and regions within the forest products industry?

iii. What were the medium-term effects (the year following the lockdown) on stock returns and risk across subsectors and regions within the forest products industry?

Analyzing a specific industry, Maneenop and Kotcharin (2020) used data from 52 listed airline stocks to examine the short-term impact of COVID-19 on the international airline industry. Their findings showed overreactions to the WHO declaration among market investors as well as regional differences. Whereas the stock prices of Asia-based airlines suffered less than the rest of the group (potentially due to government policies), US and Canadian airlines experienced a dramatic negative impact and overreaction following the declaration. If a similar development in the forest products industry globally is found, this could shed light on market investor reactions to catastrophic events on this industry and how they differ between different wood value chains and regions.

The remainder of the paper is organized as follows. In Section 2, we describe the sample and conduct some initial analyses. The section also presents our methodological approach and other related studies and how the existing methods are applied to the forest products industries. The empirical results are provided in Section 3. In Section 4, we present the main conclusions and implications of the study. 


\section{Materials and Methods}

\subsection{Data and Initial Analysis}

As stock returns are required for event analysis, we compiled data only from publicly traded firms in the forest products industry. We extracted daily closing prices and market values in US dollars for individual stocks (adjusted for dividends) within the forestry ${ }^{1}$ and paper $^{2}$ subsectors-as defined by the Industry Classification Benchmark (FTSE Russell 2021) - from the Refinitiv Datastream database over the period 11 January 2019 to 11 January 2021. As several of the stocks were traded on different stock exchanges, we chose to use data from the exchange in the country in which the company head office was located. Furthermore, we included only class A or ordinary stocks. Firms with no traded stocks during most or all of the period of analysis (and, thus, no change in stock price) were excluded from the analysis. The remaining firms were grouped according to the subsectors and regions specified in Table 1. A total of 340 different stocks were analyzed, of which 224 were registered within the paper subsector and 116 within the forestry subsector.

Table 1. Number of firms in the sample divided into regions and subsectors.

\begin{tabular}{cccc}
\hline Region & Paper & Forestry & Total \\
\hline Europe & 31 & 24 & 55 \\
North America & 16 & 19 & 35 \\
Asia & 161 & 62 & 223 \\
Southern & 16 & 11 & 27 \\
\hline Total & 224 & 116 & 340 \\
\hline
\end{tabular}

${ }^{*}$ A compilation of South America, Africa, and Oceania.

Most of the firms (223/340) are located in Asia, with the remainder spread across the other three regions. Overall, there are roughly twice as many firms within the paper subsector compared with the forestry subsector, except for North America, which has more forestry subsector firms.

Table 2 reports the market value of the firms as of 1 January 2020. In line with the results on the number of the firms, we find that total market value for the Paper subsector is highest in Asia; however, market value is more evenly distributed than firm numbers, indicating that the firms are larger in the other regions than those in Asia. For the forestry subsector, North America stands out as the region where the firms have the highest market value and, given the small number of firms, these are relatively large firms compared with those in other regions.

Table 2. Market value as of 1 January 2020 in the sample divided into regions and subsectors (million USD).

\begin{tabular}{cccc}
\hline Region & Paper & Forestry & Total \\
\hline Europe & 38,946 & 1061 & 40,007 \\
North America & 27,332 & 15,276 & 42,608 \\
Asia & 57,414 & 9598 & 67,012 \\
Southern * & 26,599 & 1853 & 28,452 \\
\hline Total & 150,290 & 27,789 & 178,079 \\
\hline
\end{tabular}

${ }^{*}$ A compilation of South America, Africa, and Oceania.

As an initial analysis, we constructed a world index for both the forestry and paper subsectors, weighting the price of each individual stock with its share of total world market value within its subsector. The computed forestry and paper subsector indices are plotted against the Morgan Stanley Capital International (MSCI) world index (MSCI 2021) in Figure 1. 


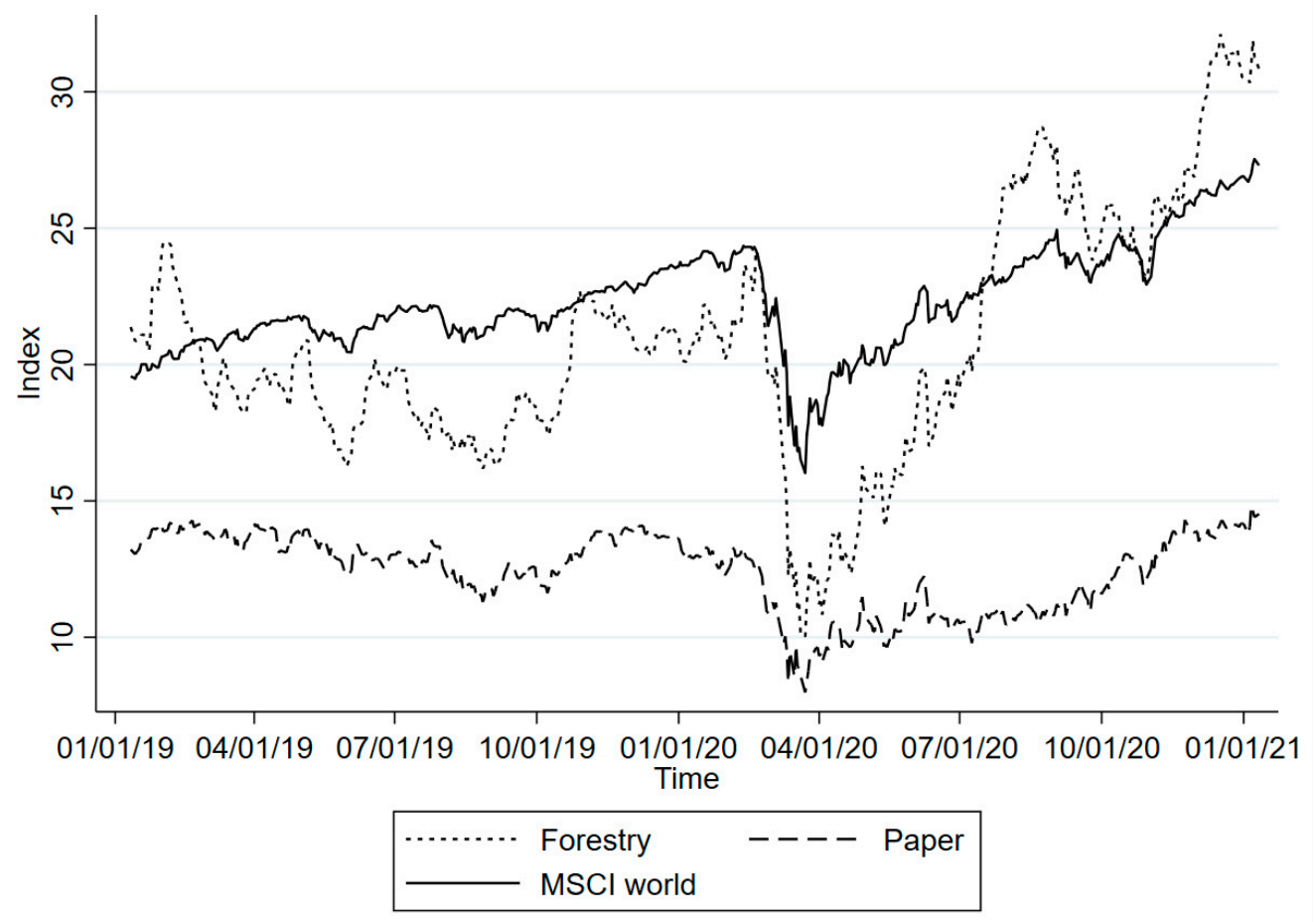

Figure 1. Computed index for the paper and forestry subsectors and the MSCI world index. MSCI index data are divided by 100 for easy comparison.

Figure 1 clearly indicates the effect of the outbreak of the COVID-19 pandemic in February and March 2020 and the dramatic drop in stock values, with the forestry subsector being hit harder than both the paper subsector and the total stock market. In addition, Figure 1 shows that all markets appear to have recovered during 2020 to levels that supersede those of the period prior to the outbreak of the pandemic.

Using the individual daily stock data, we calculate the daily logarithmic returns. In Tables 3 and 4, we present the average daily returns and volatility, respectively. While forestry stocks produced approximately the same returns in the pre-event period as paper stocks, the drop they experienced during the event period was far larger. Returns in the post-event period appear also to have been larger for forestry stocks. Forestry stocks have been more volatile in both the event and post-event periods.

Table 3. Average daily logarithmic returns.

\begin{tabular}{lccc}
\hline & Paper & Forestry & MSCI World \\
\hline Whole period: 11 January 2019-11 January 2021 & $0.02 \%$ & $0.07 \%$ & $0.06 \%$ \\
Pre-event period: 11 January 2019-31 December 2019 & $0.01 \%$ & $-0.01 \%$ & $0.07 \%$ \\
Pre-event period: 1 January 2020-3 March 2020 & $-0.40 \%$ & $-0.20 \%$ & $-0.17 \%$ \\
Event period: 4 March 2020-18 March 2020 & $-1.93 \%$ & $-5.08 \%$ & $-2.35 \%$ \\
Post-event period: 19 March 2020-11 January 2021 & $0.23 \%$ & $0.48 \%$ & $0.23 \%$ \\
\hline
\end{tabular}

Table 4. Average daily logarithmic returns.

\begin{tabular}{lccc}
\hline & Paper & Forestry & MSCI World \\
\hline Whole period: 11 January 2019-11 January 2021 & $2.33 \%$ & $2.78 \%$ & $1.36 \%$ \\
Pre-event period: 11 January 2019-31 December 2019 & $1.44 \%$ & $1.75 \%$ & $0.61 \%$ \\
Pre-event period: 1 January 2020-3 March 2020 & $1.77 \%$ & $2.44 \%$ & $1.13 \%$ \\
Event period: 4 March 2020-18 March 2020 & $8.81 \%$ & $8.28 \%$ & $5.67 \%$ \\
Post-event period: 19 March 2020-11 January 2021 & $2.47 \%$ & $3.06 \%$ & $1.40 \%$ \\
\hline
\end{tabular}


We note that the forestry stocks, despite a slight decline in 2019 (pre-event), had returns that were comparable with those of the world stock market index when looking at the whole sample. However, they are clearly far riskier compared with the whole market or the paper subsector. The returns on forestry stocks experienced a dramatic fall during the event period in March 2020 of more than twice that experienced by the market or the paper subsector stocks in the same period. Conversely, forestry stocks doubled their return in the post-event period. Paper stocks, although clearly riskier, had a comparable average return to that of the total stock market.

The WHO declaration of the pandemic clearly defined an event worthy of investigation. Moreover, the number of confirmed cases began to increase dramatically in September 2020 in what was called the "second wave" of COVID-19. This development could also have affected the stock market and market investor reactions, as fear might become more prominent and increase risk.

Our initial analysis supports the impression that the forestry subsector was hit harder than the paper subsector and the stock market as a whole in the initial phase when the pandemic was announced but has recovered well during the post-event period. However, it is unclear whether this was due to market investor overreaction. Furthermore, it is worth examining the post-event period and whether it affected the financial performance and riskiness of the forest products industry. We investigate these aspects in the next stage of analysis.

The effects of the pandemic on the forest industries are investigated in two steps. First, we examine market investor reaction to the WHO declaration in March 2020 by conducting an event-study analysis. Second, we analyze changes in systematic risk in the period before and after this event by examining the parameters from an econometric estimation of the capital asset pricing model (CAPM) (see Treynor [1962] 1999; Sharpe 1964; Lintner 1965a, 1965b; Mossin 1966).

\subsection{Event-Study Analysis}

Event studies measure abnormal returns, that is, the actual return minus the expected return, associated with an event. Following the seminal paper of Fama et al. (1969), a number of studies have used the event-study methodology to test the effect of a particular event. This method is widely used in economics and finance to examine the price behavior of securities around an event (see Brown and Warner 1985; MacKinlay 1997; Binder 1998). Studies of the bankruptcy of the Lehman Brothers during the financial crisis in 2008 are a prime example. Similarly, the COVID-19 pandemic announcement marks a specific event and it has been the subject of a number of event studies of the stock market (e.g., Harjoto et al. 2020; Liu et al. 2020; Singh et al. 2020; Størdal et al. 2020).

In the analysis of forestry and the forest products industry, the event-study approach has largely been used to analyze the effects of changes in timberland (Sun and Zhang 2011; Sun et al. 2013), industrial ownership (Mei and Sun 2008; Piao et al. 2017), policy reforms, (Zhang and Binkley 1995; Niquidet 2008; Zhang et al. 2020) or trading agreements (Malhotra and Gulati 2010).

In event studies, market models are generally preferred to the CAPM to estimate expected returns (MacKinlay 1997; Cable and Holland 1999). The market model approach assumes that there is a stable relationship between the market return and the security return in an estimation period before the event period. Then, the predicted values can be used as expected returns or the benchmark returns in the event period. More formally, expected returns from the market model are estimated as:

$$
R_{i t}=\alpha_{i}+\beta_{i} R_{m t}+\varepsilon_{i t}, E\left(\varepsilon_{i t}=0\right), \text { and } \operatorname{var}\left(\varepsilon_{i t}\right)=\sigma_{\varepsilon_{t}}^{2},
$$

where $R_{i t}$ and $R_{m t}$ are the returns on security $i$ and on the market portfolio, respectively, for the time period $t, \varepsilon_{i t}$ is the zero mean disturbance term, and $\alpha_{i}, \beta_{i}$, and $\sigma_{\varepsilon_{t}}^{2}$ are the parameters of the model. 
We define the timeline of the event study to include an estimation window to estimate a benchmark return, an event window, which should be relatively short to mitigate effects from information that is not relevant for stock prices, and a post-event window. We indexed returns at the event time by $\tau$, where $\tau=0$ is the event date and $\tau=T_{1}+1$ to $\tau=T_{2}$ represent the event window.

Given the market model parameter estimates from (1), and letting $\tau=T_{1}+1, \ldots, T_{2}$, we estimated abnormal returns as:

$$
A R_{i \tau}=R_{i \tau}-E\left(R_{i \tau}\right)=R_{i \tau}-\hat{\alpha}_{i}-\hat{\beta}_{i} R_{m \tau}
$$

In other words, we used the predicted estimates from (1) to estimate the expected returns and then estimate the abnormal returns in the event windows.

We aggregated the abnormal returns in two dimensions, through time and across stocks, to draw overall inferences for the event of interest. In the event period, cumulative abnormal returns, $C A R_{i}\left(\tau_{1}, \tau_{2}\right)$, were defined as:

$$
\operatorname{CAR}_{i}\left(\tau_{1}, \tau_{2}\right)=\sum_{\tau=\tau_{1}}^{\tau_{2}} A R_{i \tau}
$$

Next, cumulative average abnormal returns were calculated across all stocks as:

$$
\overline{\mathrm{CAR}}\left(\tau_{1}, \tau_{2}\right)=\frac{1}{N} \sum_{i=1}^{N} \mathrm{CAR}_{i}\left(\tau_{1}, \tau_{2}\right),
$$

where the variance is $\operatorname{var}\left(\overline{C A R}\left(\tau_{1}, \tau_{2}\right)\right)=\frac{1}{N^{2}} \sigma_{i}^{2}\left(\tau_{1}, \tau_{2}\right)$, and Ho is commonly tested using:

$$
\theta_{1}=\frac{\overline{C A R}\left(\tau_{1}, \tau_{2}\right)}{\operatorname{var}\left(\overline{C A R}\left(\tau_{1}, \tau_{2}\right)\right)^{1 / 2}} \sim N(0,1)
$$

However, even low cross-sectional correlation will seriously infer the disturbance term when the event date is the same for all firms. To correct for this, we apply the transformation suggested by Boehmer et al. (1991) with the adjustment made by Kolari and Pynnönen (2010). Thus, the scaled $t$-test statistic accounting for both cross-sectional and event-induced volatility in testing for the average event effect is:

$$
\theta_{2}=\frac{\overline{\operatorname{SCAR}}\left(\tau_{1}, \tau_{2}\right)}{\operatorname{var}\left(\overline{\operatorname{SCAR}}\left(\tau_{1}, \tau_{2}\right)\right)^{1 / 2}}=\frac{\overline{\operatorname{SCAR}}\left(\tau_{1}, \tau_{2}\right) \sqrt{N}}{\operatorname{var}\left(\operatorname{SCAR}\left(\tau_{1}, \tau_{2}\right)\right)^{1 / 2} \sqrt{1+(N-1) \bar{r}}}
$$

where $\overline{S C A R}$ is the scaled cumulative average abnormal returns (Patell 1976), $\mathrm{n}$ is the number of firms, $\bar{r}$ is the average of the sample cross-correlations of the estimation period residuals, and $\operatorname{var}_{S C A R_{i}}=\frac{s^{2}}{1-\bar{r}}$ is a feasible estimator of the variance of the scaled cumulative abnormal returns, so that $E\left[s^{2}\right]=(1-\bar{\rho}) \sigma_{S C A R}^{2}$, where $\bar{\rho}$ is the average correlation of the abnormal returns.

As the announcement event affected all stocks on the same day, there was no overlap of events in the event window and, therefore, there is no clustering problem. The estimation window used was from 11 January 2019 to 31 December 2019. The event period is defined as five trading days ( 1 week) prior to and after the WHO pandemic declaration date of 11 March 2020, i.e., a total of 10 trading days. The study was implemented in Stata using the add-in package "estudy" (Pacicco et al. 2017).

\subsection{Risk Analysis}

The event study captures the effects of the sudden shock on the market. However, an event such as the COVID-19 pandemic might cause more long-term changes in stock returns and their systematic risk. To capture these effects, we conducted an econometric 
estimation of the CAPM along the lines of Mei and Sun (2008). The CAPM has previously been applied to the forest sector by Olsen and Terpstra (1981), who analyzed risk, return, and competition in a major spot log market in Oregon for 1968-1978. Sun and Zhang (2001) applied the CAPM and arbitrage pricing theory to assess the financial performance of eight forestry-related investment vehicles. Liao et al. (2009) investigated the financial performance of investments in timberland and timber and their correlations with nonforestry financial assets in the US. Wan et al. (2013) used the Fisher hypothesis and the CAPM under inflation to analyze how effectively private and public equity timberland assets hedged actual, expected, and unexpected inflation in the US for 1987-2009. Yao et al. (2014) used an intertemporal CAPM to assess the risk-return relationship between forestry-related assets in the US and innovations in state variables using quarterly returns from 1988 to 2011.

The CAPM states that the systematic risk of risky assets determines their expected return, so that:

$$
R_{i t}-R_{f t}=\alpha_{i}+\beta_{i}\left(R_{m t}-R_{f t}\right)+\mu_{i t}, E\left(\mu_{i t}=0\right), \text { and } \operatorname{var}\left(\mu_{i t}\right)=\sigma_{\mu_{t}}^{2}
$$

where $R_{f t}$ is the return on a risk-free asset at time $t . \beta_{i}$ (beta) is a measure of the assets' systematic risk, while $\alpha_{i}$ (alpha) captures the abnormal return of the asset. In general, rising betas are an indication of increasing undiversifiable risk.

Contrary to Mei and Sun (2008), who employed a dummy variable to capture the effect of changes in systematic risk, we impose dynamics on the model by applying a rolling estimation of the CAPM, letting $\beta_{i}$ and $\alpha_{i}$ vary over a predefined time span. Thus, a rolling estimation of $(7)$ is given by:

$$
R_{i t}-R_{f t}=\alpha_{i \widetilde{t}}+\beta_{i \widetilde{t}}\left(R_{m t}-R_{f t}\right)+\mu_{i t} E\left(\mu_{i t}=0\right), \text { and } \operatorname{var}\left(\mu_{i t}\right)=\sigma_{\mu_{t}}^{2} .
$$

We chose a window length of $\tilde{t}=100$ days. A window period that is too short will introduce unnecessary noise and reduce estimation precision, whereas one that is too long will smooth out interesting details and reduce the timeliness of the estimation. While choosing 100 days is rather arbitrary, in our view, this window length will take both these effects into account. A rolling estimation of the CAPM is the simplest approach to modeling time-varying betas and a key benefit is that the method is robust to misspecifications, although time variation within the windows is ignored (Cosemans et al. 2016).

We calculated estimates of model parameters for each subsector and region with a rolling 100-day window for 2020, so that the estimates for 1 January 2020 are done with data 100 trading days ahead of this date.

\section{Results}

Table 5 shows the cumulative average abnormal return $(\overline{C A R})$ results from our eventstudy estimation of the WHO declaration. We report the findings for all regions, separately and combined. In addition, we present the results for the whole forest products industry sector, as well as those for the forestry and paper subsectors for all regions ${ }^{3}$. These tests supported the null hypothesis that the time-series are stationary. We also tested for serial correlation of returns for both paper and forestry and for market returns. For this purpose, we used the test by Cumby and Huizinga (1992) for serial correlation and found no autocorrelation. 
Table 5. Cumulative average abnormal return results from event-study estimations for the whole sector, subsectors (forestry and paper), and regions. T_0 = 11 March 2020, i.e., the date of the WHO announcement. A window of five trading days before and after the event date is used.

\begin{tabular}{|c|c|c|c|}
\hline & Whole Sector & Forestry & Paper \\
\hline $\begin{array}{l}\text { All regions } \\
\text { Full sample }\end{array}$ & $-10.8 \%$ *** & $-13.8 \% * * *$ & $-9.3 \% * * *$ \\
\hline $\begin{array}{c}\text { Regions } \\
\text { Europe } \\
\text { North America } \\
\text { Asia } \\
\text { Southern }^{+}\end{array}$ & $\begin{array}{l}-8.3 \% \text { ** } \\
-11.6 \% \text { * } \\
-11.0 \% \text { ** } \\
-12.7 \% \text { ** }\end{array}$ & $\begin{array}{c}-8.3 \% \%^{* *} \\
-22.1 \% \%^{* * *} \\
-13.5 \% \\
-12.9 \%^{* * *}\end{array}$ & $\begin{array}{c}-8.3 \% \text { ** } \\
-1.0 \% \\
-10.0 \% \text { ** } \\
-12.6 \% \text { *** }\end{array}$ \\
\hline
\end{tabular}

Note: The symbols ${ }^{*}, * *$, and ${ }^{* * *}$ denote that $p<0.10, p<0.05$, and $p<0.01$, respectively. ${ }^{\dagger}$ A compilation of South America, Africa, and Oceania.

Both subsectors and all regions experienced a significant drop in $(\overline{C A R}) \mathrm{s}$ during the event. The whole sector experienced a $10.8 \%$ drop and the forestry subsector experienced a somewhat larger drop of $13.8 \%$. The impact was less overall in Europe $(-8.3 \%)$, and the mean effect between the forestry and paper subsectors was quite similar. By contrast, in North America, the forestry subsector experienced a $22.1 \%$ drop in $(\overline{C A R})$, whereas there was no significant change in the paper subsector. In Asia, the forestry subsector was impacted somewhat more negatively than paper. In the Southern region, as for Europe, the impact was more or less the same for the two subsectors.

Figure 2 shows the development of the alpha and beta parameters from the rolling 100-day window CAPM estimations. There is a weak negative alpha for most of the period in the paper subsector, although a zero alpha is well within the confidence interval. The beta values slide downward but remain within the 1-1.5 interval. We observe a spike both in the period around the WHO declaration as well as at the start of the second wave in the fall of 2020.

Some of the same patterns for the estimated alpha values for the paper subsector are found for forestry. The alphas are close to zero but seem to vary more than those for the paper subsector. The beta values escalate for the whole period leading toward the second wave and we observe a more distinct peak in this period, with estimated mean beta values around 2. Moreover, the beta values clearly fall toward the end of the period.

Figure 3 reports estimated alpha and beta values in the different regions for the forestry and paper subsectors. As expected, the alpha values are small for both the forestry and paper subsectors and for all regions. There is some volatility, but it is small in absolute magnitude. However, there is a clear tendency for the alpha values to spike in the forestry subsector for North America and especially for Asia in the period from July to September, indicating an increased abnormal return. 

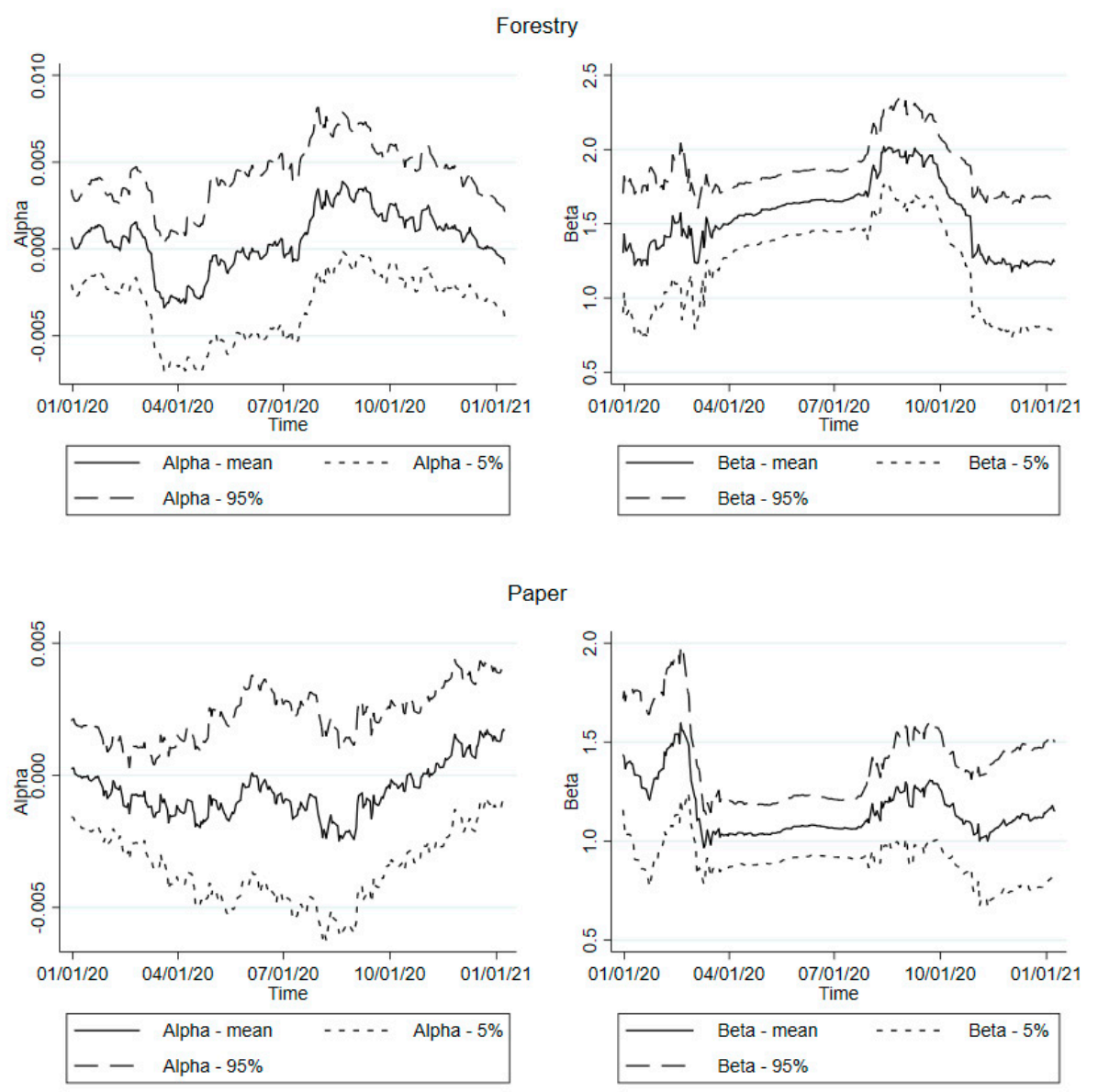

Paper

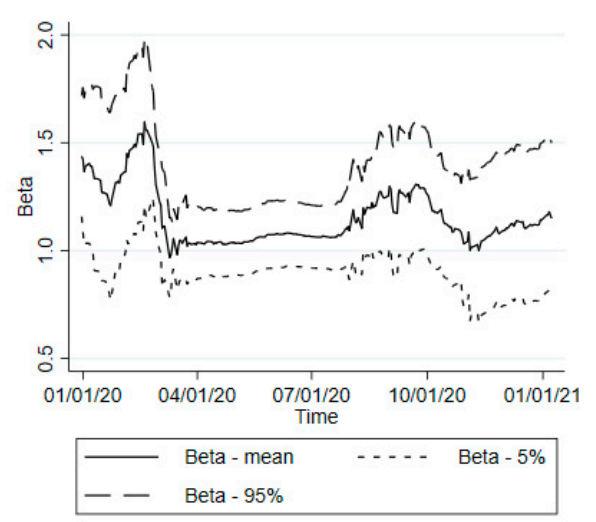

Figure 2. Development of the alpha and beta parameters from the rolling 100-day window CAPM estimations for the forestry and paper subsectors. Solid lines represent mean values, dotted lines represent $5 \%$ confidence levels, and dashed lines represent $95 \%$ confidence levels.

The beta values show a somewhat different pattern for the different regions with regard to the subsectors. For forestry, the beta values spiked at the start of 2020 for both Europe and the Southern region. Thereafter, they rapidly declined and remained relatively stable around 0.6 in Europe and 0.2 in the Southern region. However, we observe a slight dip around the time that the information about the second wave was released. In North America, the beta value steadily increased toward the fall and spiked to a level around 1.7 in October, before falling toward 1.0 at the end of the period. In contrast, in Asia there is a distinct dip in the beta value in September.

For the paper subsector, beta values were relatively stable during the whole period. In the Southern region, however, the beta values declined throughout the period, with a distinct dip at the end of summer 2020. 
Europe
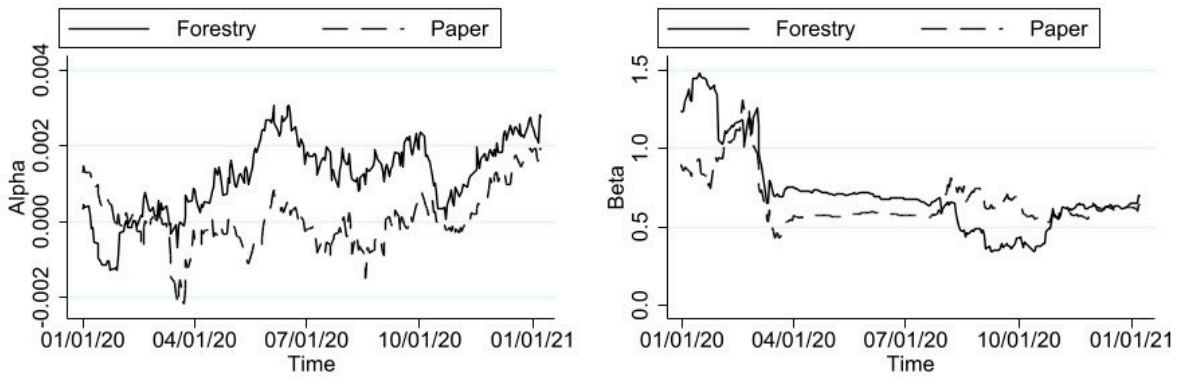

North America
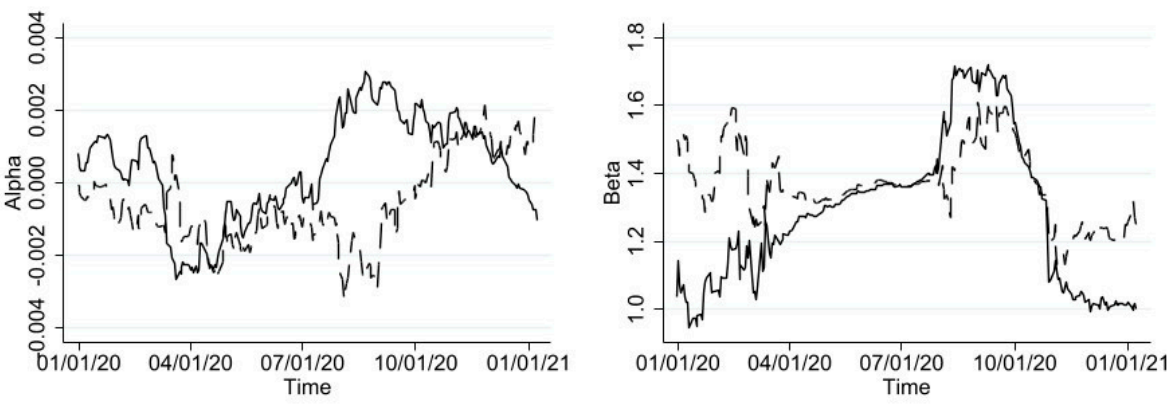

Asia
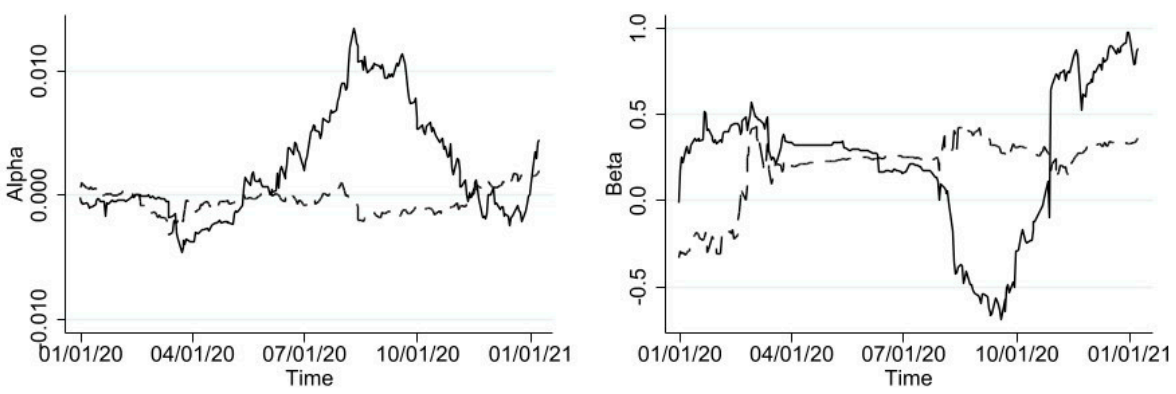

Southern
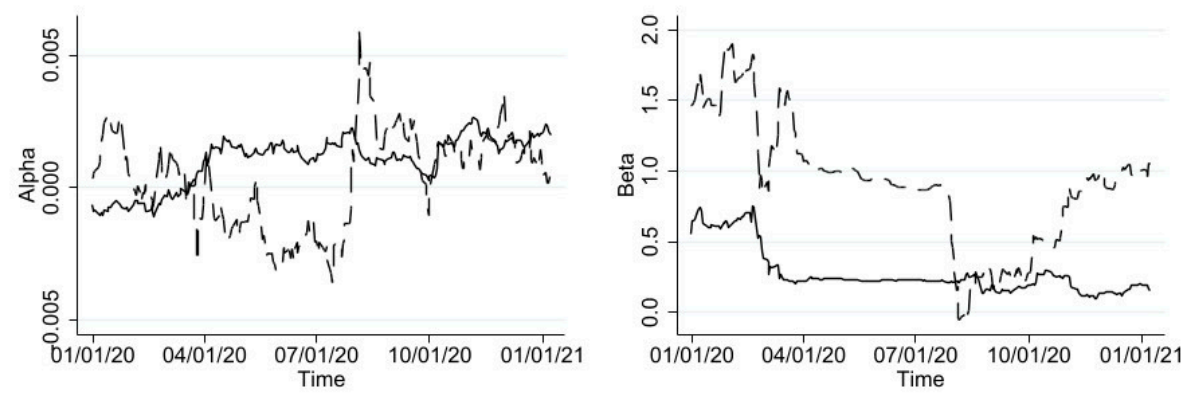

Figure 3. Development of mean values of the alpha and beta parameters from the rolling 100-day window CAPM estimations for the two subsectors in the four different regions.

\section{Discussion}

Like most other industries, the forest products industry globally was hit hard by the outbreak of the COVID-19 pandemic. In order to address the first two research questions related to what the initial effects of the pandemic and lockdowns on the stock market returns were of the forest products industries and how these varied in magnitude across subsectors and regions, we conducted an event-study analysis. Our analysis shows that 
the forestry subsector was impacted more than the paper subsector in the period around the WHO declaration of the global pandemic. This effect was most prominent in North America, with the sectoral differences being smaller in the other regions. Although there is no clear evidence based on the analysis, this could possibly be explained by the fact that there are larger firms in this region as measured by their market value compared with the other regions, especially for forestry subsector.

The markets for both subsectors recovered during 2020, with the forestry subsector growing most rapidly after the initial shock. Initial tests suggested that volatility increased more for forestry during 2020. To answer the third research questions related to the medium-term effects on stock returns and risk across subsectors and regions within the forest products industry, we conducted, using the CAPM, a more formal test for changes in systematic risk, investigating whether the beta values have changed. We found that there was a tendency for systematic risk to increase in the forestry subsector during 2020 up until October, when it experienced a sudden drop. This effect was most clear in North America. Conversely, the paper subsector has experienced more stable development.

Overall, we found that the pandemic outbreak and declaration in March 2020 had a direct negative effect on both sectors and all regions. The paper subsector experienced only minor changes in systematic risk, whereas systematic risk increases were more prominent in the forestry subsector and in North America.

Our study shows that the forestry subsector might be more volatile and react more to catastrophic events than does the paper production subsector. As such, our results support Ince and Nepal (2012), who found that sawn wood production (which is included in the forestry subsector) is more cyclical and is highly affected by economic crises through the housing construction sector. Pulp and paper production are capital-intensive and operate with more continuous production compared with sawmills. More price-elastic supply and income/GDP-elastic demand result in a more volatile forestry/solid wood sector (see e.g., Buongiorno 1978, 1979, 2015; on demand elasticities for forest products).

The trade-off between risk and return is one of the central issues faced by those who trade equities, manage portfolios, or engage in capital budgeting within the paper and forest products industry. Since the performance of the forest products industry varies with changing economic conditions, market participants should adjust to these market shifts by considering different scenarios, such as expansions and recessions.

Author Contributions: Conceptualization, S.S. and G.L.; methodology, S.S. and G.L.; software, G.L.; validation, G.L.; formal analysis, S.S., G.L. and E.T.; resources, S.S., G.L. and E.T.; data curation, S.S.; writing-original draft preparation, S.S.; writing-review and editing, S.S., G.L. and E.T.; visualization, S.S., G.L. and E.T.; supervision, S.S. and G.L.; project administration, S.S. All authors have read and agreed to the published version of the manuscript.

Funding: This research received no external funding.

Data Availability Statement: We extracted daily closing prices and market values in US dollars for individual stocks (adjusted for dividends) within the forestry and paper subsectors-as defined by the Industry Classification Benchmark (FTSE Russell 2021)—from the Refinitiv Datastream database.

Conflicts of Interest: The authors declare no conflict of interest.

\section{Notes}

1 The forestry subsector (code 55101010) is defined as: “Owners and operators of timber tracts, forest tree nurseries and sawmills. Excludes providers of finished wood products such as wooden beams, which are classified under Building Materials. Also excludes timber REITs, which are classified under Real Estate" (FTSE Russell 2021; row 144). REIT is an abbreviation for Real Estate Investment Trust.

2 The paper subsector (code 55101015) is defined as: “Companies that manufacture and market paper products including office paper, cardboard, tissue paper, newsprint, commercial pulp, etc" (FTSE Russell 2021; row 145).

3 We tested for stationarity of returns for both paper and forestry and for market returns, using the Phillips-Perron unit-root test (Phillips and Perron 1988) 


\section{References}

Binder, John. 1998. The event study methodology since 1969. Review of Quantitative Finance and Accounting 11: 111-37. [CrossRef]

Boehmer, Ekkehart, Jim Musumeci, and Annette B. Poulsen. 1991. Event study methodology under conditions of event induced variance. Journal of Financial Economics 30: 253-72. [CrossRef]

Booth, Darci, and Ilan Vertinsky. 1991. Strategic positioning in a turbulent environment: An empirical study of determinants of performance in the North American forest industry. Forest Science 37: 903-23. [CrossRef]

Brown, Stephen J., and Jerold Warner. 1985. Using daily stock returns: The case of event studies. Journal of Financial Economics 14: 3-31. [CrossRef]

Buongiorno, Joseph. 1978. Income and price elasticities in the world demand for paper and paperboard. Forest Science 24: $231-46$. [CrossRef]

Buongiorno, Joseph. 1979. Income and price elasticities of demand for sawn wood and wood-based panels: A pooled cross-section and time-series analysis. Canadian Journal of Forest Research 9: 141-48. [CrossRef]

Buongiorno, Joseph. 2015. Income and time dependence of forest product demand elasticities and implications for forecasting. Silva Fennica 49: 1395. [CrossRef]

Cable, Jo, and Kevin Holland. 1999. Modelling normal returns in event studies: A model-selection approach and pilot study. European Journal of Finance 5: 331-41. [CrossRef]

Cosemans, Mathijs, Rik Frehen, Peter C. Schotman, and Rob Bauer. 2016. Estimating security betas using prior information based on firm fundamentals. Review of Financial Studies 29: 1072-112. [CrossRef]

Cumby, Robert. E., and John Huizinga. 1992. Testing the autocorrelation structure of disturbances in ordinary least squares and instrumental variables regressions. Econometrica 60: 185-95. [CrossRef]

Fama, Eugene F., Lawrence Fisher, Michael C. Jensen, and Richard Roll. 1969. The adjustment of stock prices to new information. International Economic Review 10: 1-21. [CrossRef]

FAO. 2020. Impacts of COVID-19 on Wood Value Chains and Forest Sector Response: Results from a Global Survey 2020. Rome: Food and Agriculture Organization. [CrossRef]

FAO. 2021. FAOSTAT. Forestry Production and Trade. Available online: http://www.fao.org/faostat/en/\#data/FO (accessed on 24 February 2021).

FTSE Russell. 2021. FTSE Russell's Industry Classification Benchmark. Available online: https:/ /www.ftserussell.com/files/supportdocument/icb-structure-definitions (accessed on 24 February 2021).

Harjoto, Maretno A., Fabrizio Rossi, and John K. Paglia. 2020. COVID-19: Stock market reactions to the shock and the stimulus. Applied Economic Letters. [CrossRef]

Hurmekoski, Elias, and Lauri Hetemäki. 2013. Studying the future of the forest sector: Review and implications for long-term outlook studies. Forest Policy and Economics 34: 17-29. [CrossRef]

Ince, Peter J., and Prakash Nepal. 2012. Effects on U.S. timber outlook of recent economic recession, collapse in housing construction, and wood energy trends. In General Technical Report FPL-GTR-219. Madison: U.S. Department of Agriculture, Forest Service, Forest Products Laboratory. [CrossRef]

Jonsson, Ragnar. 2011. Trends and possible future in global forest-product markets-Implications for the Swedish forest sector. Forests 2: 147-67. [CrossRef]

Kolari, James W., and Seppo Pynnönen. 2010. Event study testing with cross-sectional correlation of abnormal returns. Review of Financial Studies 23: 3996-4025. [CrossRef]

$\mathrm{Li}$, Yanshu, and Daowei Zhang. 2014. Industrial timberland ownership and financial performance of US forest products companies. Forest Science 60: 569-78. [CrossRef]

Liao, Xianchun, Yaoqi Zhang, and Changyou Sun. 2009. Investments in timberland and softwood timber as parts of portfolio selection in the United States: A cointegration analysis and capital asset pricing model. Forest Science 55: 471-79. [CrossRef]

Lintner, John. 1965a. The valuation of risk assets and the selection of risky investments in stock portfolios and capital budgets. Review of Economics and Statistics 47: 13-37. [CrossRef]

Lintner, John. 1965b. Security prices, risk and maximal gains from diversification. Journal of Finance 20: 587-615. [CrossRef]

Liu, HaiYue, Aqsa Manzoor, CangYu Wang, Lei Zhang, and Zaira Manzoor. 2020. The COVID-19 outbreak and affected countries stock markets response. International Journal of Environmental Research and Public Health 17: 2800. [CrossRef]

MacKinlay, A. Craig. 1997. Event studies in economics and finance. Journal of Economic Literature 35: 13-39.

Malhotra, Nisha, and Sumeet Gulati. 2010. The effects of the 1996 U.S.-Canada softwood lumber agreement on the industrial users of lumber: An event study. Contemporary Economic Policy 28: 275-87. [CrossRef]

Maneenop, Sakkakom, and Suntichai Kotcharin. 2020. The impacts of COVID-19 on the global airline industry: An event study approach. Journal of Air Transport Management 89: 101920. [CrossRef]

Mei, Bin, and Changyou Sun. 2008. Event analysis of the impact of mergers and acquisitions on the financial performance of the U.S. forest products industry. Forest Policy and Economics 10: 296-94. [CrossRef]

Mossin, Jan. 1966. Equilibrium in a capital asset market. Econometrica 35: 768-83. [CrossRef]

MSCI. 2021. MSCI-World Stock Market Index. Available online: https:/ /www.msci.com/documents/10199/178e6643-6ae6-47b9-82bee1fc565ededb (accessed on 24 February 2021). 
Niquidet, Kurt. 2008. Revitalized? An event study of forest policy reform in British Columbia. Journal of Forest Economics 14: 227-41. [CrossRef]

Olsen, Robert A., and Robert H. Terpstra. 1981. An application of capital asset pricing to the spot market for softwood logs in Oregon. Forest Science 27: 215-23. [CrossRef]

Pacicco, Fausto, Luigi Vena, and Andrea Venegoni. 2017. Running event studies using Stata: The estudy command. SSRN Electronic Journal. [CrossRef]

Patell, James M. 1976. Corporate forecasts of earnings per share and stock price behavior. Empirical tests. Journal of Accounting Research 14: 246-76. [CrossRef]

Phillips, Peter C. B., and Pierre Perron. 1988. Testing for a unit root in time series regression. Biometrika 75: 335-46. [CrossRef]

Piao, Xiaorui, Bin Mei, and Weiyi Zhang. 2017. Long-term event study of timber real estate investment trust conversions. Forest Policy and Economics 78: 1-9. [CrossRef]

Sadorsky, Perry, and Irene Henriques. 2001. Multifactor risk and the stock returns of Canadian paper and forest products companies. Forest Policy and Economics 3: 199-208. [CrossRef]

Sharpe, William F. 1964. Capital asset prices: A theory of market equilibrium under conditions of risk. Journal of Finance 19: 425-42. [CrossRef]

Singh, Bhanwar, Rosy Dhall, Sahil Narang, and Savita Rawat. 2020. The outbreak of COVID-19 and stock market responses: An event study and panel data analysis for G-20 countries. Global Business Review, 1-26. [CrossRef]

Størdal, Ståle, Minh T. H. Dinh, Erik Haugom, and Gudbrand Lien. 2020. Norwegian stock market behavior during the initial phase of the COVID-19 pandemic. Beta-Scandinavian Journal of Business Research 34: 207-21. [CrossRef]

Sun, Changyou, and Daowei Zhang. 2001. Assessing the financial performance of forestry-related investment vehicles: Capital asset pricing model vs. arbitrage pricing theory. American Journal of Agricultural Economics 83: 617-28. [CrossRef]

Sun, Xing, and Daowei Zhang. 2011. An event analysis of industrial timberland sales on shareholder values of major U.S. forest products firms. Forest Policy and Economics 13: 396-401. [CrossRef]

Sun, Changyou, Mohammad M. Rahman, and Ian A. Munn. 2013. Adjustment of stock prices and volatility to changes in industrial timberland ownership. Forest Policy and Economics 26: 91-101. [CrossRef]

Thomson, Thomas A. 1991. Efficient combinations of timber and financial market investments in single-period and multiperiod portfolios. Forest Science 37: 461-80. [CrossRef]

Treynor, Jack L. 1999. Toward a theory of market value of risky assets. In Asset Pricing and Portfolio Performance. Edited by Korajczyk Robert A. London: Risk Books, pp. 15-22. First published 1962.

Wan, Yang, Bin Mei, Michael L. Clutter, and Jacek P. Siry. 2013. Assessing the inflation hedging ability of timberland assets in the United States. Forest Science 59: 93-104. [CrossRef]

World Health Organization. 2021. WHO Director-General's Opening Remarks at the Media Briefing on COVID-19-11 March 2020. Available online: https:/ / www.who.int/director-general/speeches/detail/who-director-general-s-opening-remarks-at-themedia-briefing-on-covid-19---11-march-2020 (accessed on 22 February 2021).

Yao, Wenjing, Bin Mei, and Michael L. Clutter. 2014. Pricing Timberland Assets in the United States by the Arbitrage Pricing Theory. Forest Science 60: 943-52. [CrossRef]

Zhang, Daowei, and Clark S Binkley. 1995. The economic effect of forest policy changes in British Columbia: An event study of stock-market returns. Canadian Journal of Forest Research 25: 978-86. [CrossRef]

Zhang, Tingting, Shunbo Yao, Jinna Yu, Assem A. Hatab, and Zhen Liu. 2020. Effects of China's collective forestland tenure reform policies on forest product firm values. Land 9: 127. [CrossRef] 